\title{
The effects of prochloraz on the levels of nuclear receptor genes expressions and global DNA methylation in human prostate carcinoma cells
}

\author{
Ecem Fatma Karaman (D), Esma Doğan² (D), Dilara Alga² (D), Sibel Özden² (D) \\ 'Biruni University, Faculty of Pharmacy, Department of Pharmaceutical Toxicology, Istanbul, Turkey \\ ${ }^{2}$ Istanbul University, Faculty of Pharmacy, Department of Pharmaceutical Toxicology, Istanbul, Turkey
}

ORCID IDs of the authors: E.F.K. 0000-0002-1504-4546; E.D. 0000-0002-0613-7433; D.A. 0000-0002-2693-6080;

S.Ö. 0000-0002-1662-2504

Cite this article as: Karaman, E. F., Dogan, E., Alga, D., \& Ozden, S. (2021). The effects of prochloraz on the levels of nuclear receptor genes expressions and global DNA methylation in human prostate carcinoma cells. İstanbul Journal of Pharmacy, $51(2), 191-197$.

\begin{abstract}
Background and Aims: Prochloraz (PCZ) is an imidazole fungicide which is used in agriculture and gardening. PCZ, with endocrine disrupting effect, disrupts reproductive and developmental functions. Previously, the effects of PCZ on the estrogen and androgen receptors have been shown in vitro and in vivo. Because of endocrine disrupting effects, PCZ could influence nuclear receptors which acted as ER and AR antagonists. Besides, PCZ has been thought to have no genotoxic effects. Therefore, we aimed to investigate possible effects of PCZ on nuclear receptor genes and epigenetic mechanisms in human prostate carcinoma (PC-3) cells.

Methods: In the present study, MTT and LDH tests were applied to evaluate the cell viability. Expression levels of nuclear receptor genes such as $A h R, P X R, P P A R \alpha, P P A R Y$ were studied on real-time quantitative PCR. For global DNA methylation analysis, the levels of 5 -methylcytosine $(5-\mathrm{mC} \%)$ were measured by elisa kit.

Results: According to MTT and LDH test results, IC50 value of PCZ has been determined as 144.19 and $116.65 \mu \mathrm{M}$, respectively. There were significant changes for the expression levels of AhR, PPAR and PPARY genes after 5-50 $\mu \mathrm{M}$ of PCZ treatments. 5 and $50 \mu \mathrm{M}$ of PCZ decreased the levels of $5-\mathrm{mC} \%$ in the rates of $22.6 \%$ and $26.9 \%$, respectively.

Conclusion: It has been suggested that PCZ may cause alterations on the expressions of nuclear receptor genes which could be related to endocrine disrupting effects and may have implications on global DNA methylation.
\end{abstract}

Keywords: Cytotoxicity, DNA methylation, nuclear receptor genes, PC-3 cells, prochloraz

\section{INTRODUCTION}

Prochloraz (PCZ) (CAS no. 67747-09-5; N-propyl-N-[2-(2,4,6trichlorophenoxy)ethyl]-1H-imidazole-1-carboxamide) is an imidazole fungicide used in gardening and agriculture. The action of imidazole fungicides is based on the blocking cytochrome P450-dependent enzyme activity, for the conversion of an essential component of fungal cell membranes (Henry \& Sisler, 1984). Exposure to PCZ, mainly through consumption of fruits and vegetables such as wheat, barley, rice, cereal, cherries, has been important worldwide (Claeys et al., 2011). PCZ exhibited low acute toxicity and has been shown to display hepatotoxic effects (Goettel et al. 2015; Heise et al., 2015, 2018; Marx-Stoelting et al., 2017), induction of oxidative stress (Lundqvist, Hellman \& Oskarsson, 2016; Alpertunga et al., 2014; Sanchez, Piccini \& Porcher, 2008), endocrine disrupting effects (Vinggaard, Hnida, Breinholt \& Larsen 2000; Vinggaard et al., 2002, 2006) and also tumorigenic effects following chronic exposure (EFSA, 2011). The modes mechanisms of action of PCZ 
were antagonism of the androgen and estrogen receptors and inhibition of steroidogenic enzymes which play a key role in biosynthesis and metabolism of steroid hormones as well as a potent aromatase inhibitor (Laier et al., 2006; Andersen, Vinggaard, Rasmussen, Gjermandsen \& Bonefeld-Jørgensen, 2002; Vinggaard et al., 2002). PCZ also showed its effects by activating the aryl hydrocarbon receptor (AhR) through up-regulation of CYP1A1 expression in different liver cell lines and rat liver (MarxStoelting et al., 2017; Halwachs, Wassermann, Lindner, Zizzadoro \& Honscha, 2013; Long et al., 2003; Vinggaard et al., 2006).

DNA methylation, one of the most studied epigenetic modifications, plays crucial roles in aging, cell proliferation and various diseases such as cancer, diabetes (Anderson, Sant \& Dolinoy, 2012; Kulis \& Esteller, 2010; Jones \& Baylin, 2007; Moggs, Goodman, Trosko, \& Roberts, 2004; Baylin, 1997). Mutagenicity and genotoxicity of PCZ have been summarized by JMPR and EFSA that PCZ exerted in some test systems with negative results except in in vitro sister chromatid exchange assay (JMPR, 2001). Based on these results, JMPR (2001) and EFSA (2011) clarified that PCZ is improbable to be potentially genotoxic. In our previous study, PCZ also showed no evidence of mutagenicity and DNA damage in NRK-52E cells (Alpertunga et al., 2014). Controversially, Lundqvist et al. (2016) have indicated that non-toxic concentrations of PCZ triggered DNA damage in HepG2 cells by Comet assay. Therefore, non-gentoxic mechanisms may have a role in PCZ toxicity. Therefore, in present study we aimed to investigate global DNA modifications of PCZ for the first time. We studied potential toxic effects of PCZ on nuclear receptor genes and global DNA methylation as an epigenetic mechanism.

\section{MATERIALS AND METHODS}

\section{Chemicals}

PCZ, Pestenal, analytical standard (purity 99.2\%), was obtained from Sigma-Aldrich Chemicals Co (St. Louis, Missouri, USA). A stock solution of PCZ was prepared by dissolving it in dimethyl sulfoxide (DMSO, Sigma-Aldrich, St Louis, Missouri, USA). Cell culture media and all other supplements were purchased from Wisent Bioproducts (Saint-JeanBaptiste, QC, Canada), and sterile plastic materials were purchased from Nest Biotechnology (Jiangsu, China). Cytotox-LDH-XTT 2 Parameter Cytotoxicity kit was used for cytotoxicity (Xenometrix AG, Allschwil, Switzerland). DNA, RNA isolation kits and cDNA synthesis kits were obtained from Roche Life Sciences (Penzberg, Upper Bavaria, Germany). 5-methylcytosine (5-mC) DNA ELISA kit was purchased from Zymo Research (Irvine, CA, USA). Syber green master mix was obtained from Bioline (London, UK), and primers for gene expressions were obtained from Sentromer DNA Technologies (Istanbul, Turkey).

\section{Cell culture and treatments}

The human prostate adenocarcinoma cell line (PC-3 cells) was obtained from American Type Culture Collection (ATCC ${ }^{\circ} \mathrm{CRL}-1435^{\mathrm{TM}}$ ) and cultured in Dulbecco's Modified Eagle's Medium/Ham's Nutrient Mixture F-12 (DMEM-F12) under standard cell culture conditions as described previously (Senyildiz, Karaman, Baş, Pirinççi, Özden, 2016, 2017).
For gene expression and global DNA methylation analysis $1 \times 10^{6}$ cells were incubated in a $25 \mathrm{~cm}^{2}$ culture flask for $24 \mathrm{~h}$ in $\mathrm{CO}_{2}$ incubator prior to the treatment. The exposure concentrations of PCZ used in the experiments have been determined with our cytotoxicity studies and based on our previous study (Alpertunga et al., 2014).

\section{Cell viability}

Effects of PCZ on cell viability were assessed by MTT [3-(4,5-dimethylthiazol-2-yl)-2,5 diphenyltetrazolium bromide, a tetrazole] and lactate dehydrogenase $(\mathrm{LDH})$ cytotoxicity tests. Principle of the MTT test; yellow MTT is reduced to purple formazan in the mitochondria of living cells by the enzyme succinate dehydrogenase, and it measures cell viability and proliferation (Alley et al., 1988; Mossman, 1983). The LDH test is a cell viability test method, based on measuring membrane integrity via \% LDH release (lactate dehydrogenase activity) (Decker \& Lohmann-Matthes, 1988; Korzeniewski \& Callewaert, 1983).

For cytotoxiciy assay, $1 \times 10^{4}$ cells (in $100 \mu \mathrm{L}$ medium) were seeded in 96-well plates and were treated with PCZ in the concentration range of 7.81-500 $\mu \mathrm{M}$ and DMSO (1\%, exposure concentration in culture media) as solvent control for $24 \mathrm{~h}$. Then, cell viability and \% LDH release were measured and assessed using the MTT and LDH test as described in our previous study (Karaman \& Ozden, 2019; Demirel, Alpertunga \& Ozden, 2015).

\section{Gene expression analysis of nuclear receptor genes}

After 5, 10 and $50 \mu \mathrm{M}$ of PCZ treatments for $24 \mathrm{~h}$, total RNA was isolated from PC-3 cells using High Pure RNA Isolation kit (Roche Life Science). Reverse transcription was performed by Transcriptor First Strand cDNA Synthesis kit from 500 ng of total RNA, and the mixture of anchored-oligo(dT) and random hexamer primers. $5 \mu \mathrm{L}$ of the 1/10 diluted RT-reaction was used as the template in real-time quantitative PCR. Gene expressions of nuclear receptor genes such as $A h R$ (aryl hydrocarbon receptor), PXR (pregnane-X receptor), PPARa (peroxisome proliferator-activated receptor alpha), PPARY (peroxisome proliferator-activated receptor gamma) were measured using BioLine SensiFast ${ }^{\text {TM }}$ Syber ${ }^{\circ}$ No-Rox kit (London, UK) on LightCycler 480 Instrument II (Roche Life Science). Primer sequences and their annealing temperatures of genes are illustrated in Table 1. Evaluations of results for all genes were performed as described previously (Karaman \& Ozden, 2019).

\section{Global DNA methylation}

5, 10 and $50 \mu \mathrm{M}$ of PCZ exposed to PC-3 cells for $24 \mathrm{~h}$, then genomic DNA was isolated from cells using the High Pure PCR Template Preparation kit (Roche Life Sciences, Penzberg, Germany) according to the instructions provided by the manufacturer. To measure global levels of DNA methylation, $100 \mathrm{ng}$ of DNA samples were applied to 5-mC DNA elisa kit (Zymo Research, Irvine, CA, USA) according to the manufacturer's instructions as previously described (Senyildiz, Karaman, Bas, Pirincci \& Ozden, 2017). Also, gene expression analysis of DNA methyltransferase genes including DNMT1 (DNA methyltransferase 1) and MGMT (O-6-methylguanine-DNA methyltransferase) were performed by real-time quantitative PCR analysis using BioLine SensiFast ${ }^{\mathrm{TM}}$ Syber ${ }^{\circ}$ No-Rox kit (London, UK). 
Karaman et al. The effects of prochloraz on the levels of nuclear receptor genes expressions and global DNA methylation in human prostate carcinoma cells

\section{Table 1. Primers used real-time PCR analysis of nuclear receptor genes, DNA methyltransferase and the} corresponding annealing temperatures.

\begin{tabular}{|c|c|c|c|}
\hline Gene & Primer sequence $\left(5^{\prime}-3^{\prime}\right)$ & $\operatorname{Tm}\left({ }^{\circ} \mathrm{C}\right)$ & Reference \\
\hline AhR & $\begin{array}{l}\text { F: TGGACAAGGAATTGAAGAAGC } \\
\text { R: AAAGGAGAGTTTTCTGGAGGAA }\end{array}$ & 53 & Ayed-Boussema et al., 2011 \\
\hline PPAR $\alpha$ & $\begin{array}{l}\text { F: CATTACGGAGTCCACGCGT } \\
\text { R: ACCAGCTTGAGTCGAATCGTT }\end{array}$ & 58 & Rogue et al., 2011 \\
\hline PPARy & $\begin{array}{l}\text { F: CTGAATGTGAAGCCCATTGAA } \\
\text { R: GTGGAAGAAGGGAAATGTTGG }\end{array}$ & 54 & Harada et al., 2005 \\
\hline DNMT1 & $\begin{array}{l}\text { F: CCTCCAAAAACCCAGCCAAC } \\
\text { R: TCCAGGACCCTGGGGATTTC }\end{array}$ & 60 & Ahmadnejad et al., 2017 \\
\hline MGMT & $\begin{array}{l}\text { F: TGCACAGCCTGGCTGAATG } \\
\text { R: GGTGAACGACTCTTGCTGGAA }\end{array}$ & 58 & Lai et al., 2008 \\
\hline$\beta$-actin & $\begin{array}{l}\text { F: AАCTACCTTCAACTCCAT } \\
\text { R: TGATCTTGATCTTCATTGTG }\end{array}$ & 48 & Rosa et al., 2009 \\
\hline
\end{tabular}

\section{Statistical analysis}

Global methylation levels (5-mC\%) and cytotoxicity results were represented as mean \pm standard deviation (SD). Statistical analysis was performed by ANOVA followed by Dunnett's multiple comparison test using "SPSS version 21.0 for Windows", statistical program (IBM Analytics, New York, USA). P values of less than 0.05 and 0.001 were selected as the levels of significance.

\section{RESULTS}

\section{Effects of PCZ on the cell viability in PC-3 cells}

We performed cytotoxicity of PCZ in the concentration range of 3.906-500 $\mu \mathrm{M}$ in PC-3 cells after $24 \mathrm{~h}$ exposure by using MTT and LDH assays. IC $C_{50}$ values of PCZ were determined as 144.19 and $116.65 \mu \mathrm{M}$, respectively. As shown in Figures 1a and 1b,
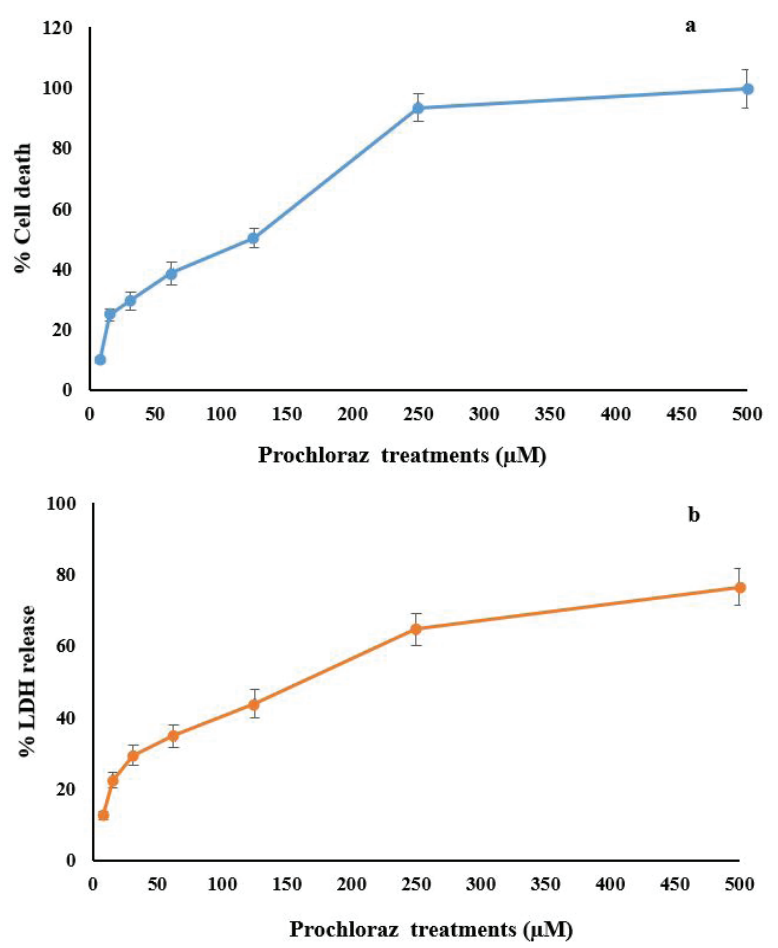

Figure 1. Effects of $P C Z(7.81,15.62,31.25,62.5,125,250$ and $500 \mu M)$ on cell viability by MTT (a) and LDH (b) tests in PC-3 cells after $24 \mathrm{~h}$ exposure. Data are presented as mean \pm SD. treatments of PCZ for $24 \mathrm{~h}$ significantly decreased the cell viability $\geq 10.13 \%$ and $\geq 12.74 \%$ for MTT and LDH tests, respectively, in comparison to the vehicle control group.

\section{Effects of PCZ on global DNA methylation in PC-3 cells}

Levels of 5-mC\% were observed after 5, 10 and $50 \mu \mathrm{M}$ treatments of PCZ for $24 \mathrm{~h}$ by elisa kit. Exposure to 10 and $50 \mu \mathrm{M}$ of $\mathrm{PCZ}$ for $24 \mathrm{~h}$ resulted in a significant decrease in 5-mC\% status (22.67\%, $\mathrm{p}<0.05$ and $26.97 \%, \mathrm{p}<0.05$, respectively) comparison with the control group (Figure 2a). Consistently, $10 \mu \mathrm{M}$ (61.9\%) and $50 \mu \mathrm{M}(85.21 \%, \mathrm{p}<0.05)$ of PCZ decreased the expression levels of DNMT1 (Figure 2a) while non-significant decrease was observed for MGMT (Figure 2b).

\section{Effects of PCZ on nuclear gene expression levels in PC-3 cells}

We analysed the gene expression of selected nuclear receptor genes (AhR, PPARa, PPARY, PXR) to investigate the potential effects of PCZ. In Figure 3, our data showed that $10 \mu \mathrm{M}$ of PCZ significantly increased expression levels of PPARa (2.63 fold, $\mathrm{p}<0.05), 10$ and $50 \mu \mathrm{M}$ of $P C Z$ significantly increased expression levels of PPARY (1.73 fold, $p<0.05$ and 3.09, $p<0.05$, respectively), and $50 \mu \mathrm{M}$ of $\mathrm{PCZ}$ significantly decreased expression levels of AhR (53.3\%, p<0.05). However, no expression of PXR gene was observed at all experiment groups, even in control group.

\section{DISCUSSION}

PCZ has hepatotoxic properties, exerts tumorigenic effects following chronic exposure and induces gene expression and enzyme activity of CYP1A in animal studies (Goettel et al. 2015; Heise et al., 2015, 2018; Marx-Stoelting et al., 2017; Sturm, Cravedi, Perdu, Baradat \& Segner 2001; Vinggaard et al., 2006). It has been reported that PCZ acts as endocrine disruptor through interfering with ER and AR as well as an aromatase inhibition, alterations in the several hormones levels and steroid biosynthesis (Andersen, Vinggaard, Rasmussen, Gjermandsen \& Bonefeld-Jørgensen, 2002; Laignelet, Riviere \& Lhuguenot, 1992; Ohlsson, Ullerås \& Oskarsson, 2009; Robitaille, Rivest \& Sanderson, 2015; Vinggaard et al., 2000, 2002, 2006). Moreover, several studies have shown that PCZ caused oxidative damage through induction of lipid peroxidation and alterations in the 


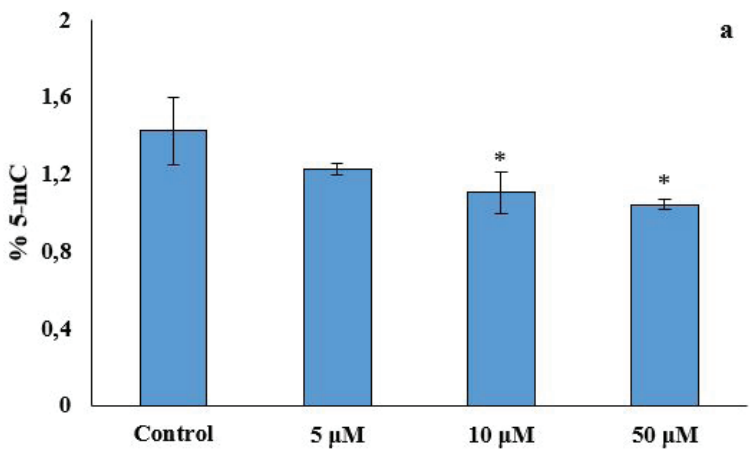

Prochloraz treatments
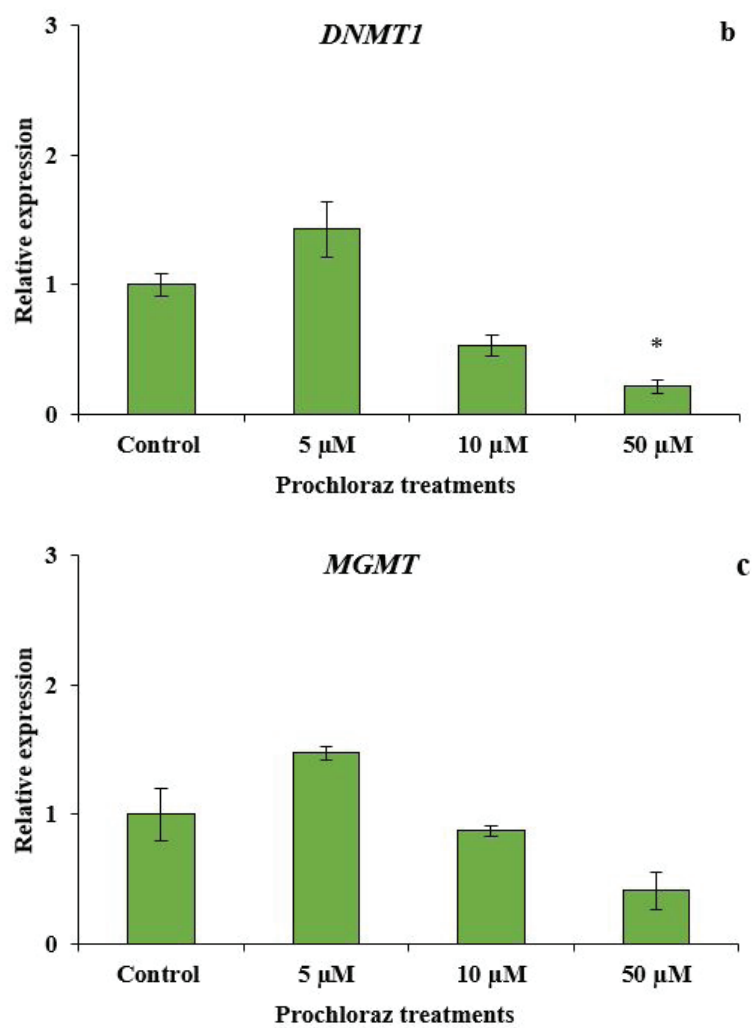

Figure 2. a) Effects of $P C Z(0-50 \mu M)$ on levels of $5-m C \%$ (a), relative gene expression levels of DNMT1 (b) and MGMT (c) in PC-3 cells after 24 $\mathrm{h}$ exposure. Data are presented as mean \pm SD. (Statistical analysis was performed by ANOVA + Dunnett post hoc test. Statistically significant changes are indicated by ${ }^{*} \mathrm{p}<0.05$ ).

levels of antioxidant enzymes and glutathione in vitro (Alpertunga et al., 2014; Lundqvist et al., 2016; Sanchez et al., 2008).

In present study, IC $C_{50}$ values of PCZ were determined as 144.19 and $116.65 \mu \mathrm{M}$ in PC-3 cells for $24 \mathrm{~h}$ by MTT and LDH tests, respectively. Our cytotoxicty results were consistent with the previous studies (Alpertunga et al., 2014; Rudzok et al., 2011; Strum et al., 2001). It has been reported that $I C_{50}$ values of PCZ were $140 \mu \mathrm{M}$ in trout hepatocytes by using LDH cytotoxicity test (Strum et al., 2001); 117, 87 and $99 \mu$ M in HepG2 cells by using MTT, neutral red uptake and Alamar Blue tests, respectively (Rudzok et al., 2011) and $110.76 \mu \mathrm{M}$ in NRK-52E rat kidney cells by using MTT test (Alpertunga et al., 2014).

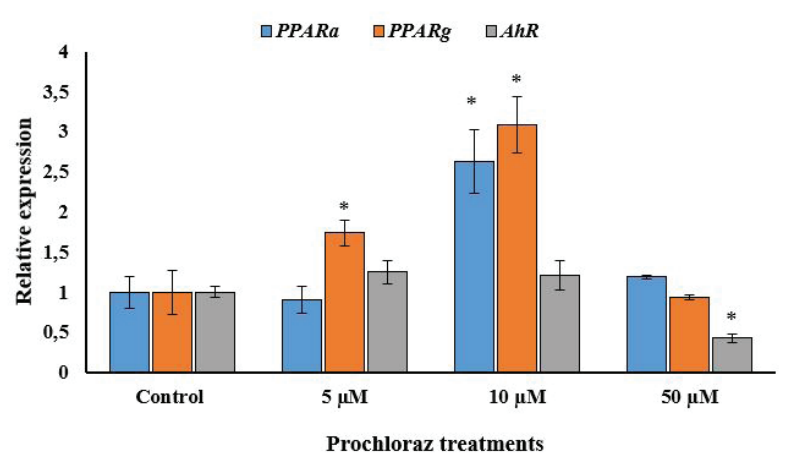

Figure 3. Effects of PCZ (0-50 $\mu \mathrm{M})$ on relative gene expression levels of AhR, PPARa, PPARY and PXR in PC-3 cells after $24 \mathrm{~h}$ exposure. Data are presented as mean \pm SD. (Statistical analysis was performed by ANOVA + Dunnett post hoc test. Statistically significant changes are indicated by $\left.{ }^{*} p<0.05\right)$.

Investigating epigenetic alterations such as DNA methylation could be useful biomarkers for the toxicity assessment of endocrine disrupting chemicals (Casati, Sendra, Sibilia \& Celotti, 2015; Greally \& Jacobs, 2013; Maqbool, Mostafalou, Bahadar \& Abdollahi, 2016). However, there has been any study on epigenetic modifications of PCZ toxicity. In present study, effects of PCZ on global DNA methylation, the most studied epigenetic alteration, have been investigated. PCZ decreased the global DNA methylation levels in a dose-dependent manner. As well as DNMT genes regulate DNA methylation in mammals. Especially, DNMT1 provides regularity and continuity of methyltransferase activity that conserves the methylation state throughout DNA replication (Das \& Singal, 2004; Pathania et al., 2015; Pradhan, Bacolla, Wells \& Roberts, 1999). Consistent with our 5-mC\% levels, expression of DNMT1 was also decreased. We can suggest that PCZ could cause global DNA methylation which is a common feature in the oncogenesis of many tumor tissues leading to genomic instability (GamaSosa et al., 1983).

One of the sensors that enables cells to continually adapt and respond to the molecular changes by the environment, diet and host metabolism is the ligand-activated transcription factor AhR which perceives both endogenous factors and exogenous factors such as environmental toxins (McIntosh, Hogenesch \& Bradfield, 2010). It has been suggested that PCZ exerts its effects by activating AhR which has an important role in PCZ-mediated hepatotoxicity (Marx-Stoelting et al., 2017; Rieke et al. 2014; Halwachs et al. 2013), and agonists of AhR could trigger tumor growth in rodent livers (Bock \& Kohle 2005). Interestingly, our findings showed that AhR gene expression significantly decreased after $50 \mu \mathrm{M}$ of PCZ in PC-3 cells. Evans et al. (2008) also have observed that higher concentrations of TCDD (2,3,7,8-tetrachlordibenzo-p-dioxin), other AhR agonist, caused a reduction of enzyme activity to $50 \%$ of the maximal response value which could reflect a negative feedback through the AhR repressor (AhRR) competition with AhR, similarly to our results.

Members of the PPAR subfamily, one of the nuclear receptors, including PPARa, PPAR $\beta / \delta$, and PPARY, are transcription 
factors that regulate by activation of fatty acids and have essential roles in several biological processes including cellular differentiation, development, and metabolism (Derosa, Sahebkar \& Maffioli, 2018; Michalik \& Wahli, 2006). There have been no studies showing the effects of PCZ on PPARs gene expression. According to our findings, PPARa and PPARY gene expression increased significantly after PCZ exposure. In the meantime, PPARa expression has been found among normal prostate and prostate cancer tissues while PPARY expression was observed only in prostate cancer (Segawa et al., 2002). It has been also suggested that PPARy acts as an oncogenic gene, and its activation promoted the development and progression of prostate cancer (Ahmad et al., 2016; Rogenhofer et al., 2012). Interestingly, it has been also reported that PPARY signaling was regulated negatively by AR signaling (Olokpa, Bolden \& Stewart, 2016). In the present study, while gene expressions of PPARa at $10 \mu \mathrm{M}$ of PCZ and PPARY at 5 and $10 \mu \mathrm{M}$ of PCZ increased with the treatment, gene expression levels were decreased non-significantly after $50 \mu \mathrm{M}$ exposure. It has been thought that these effects could be the result of nonmonotonic dose responses due to the endocrine disrupting properties of $\mathrm{PCZ}$.

In conclusion, our results, showing that PCZ is able to change nuclear receptor signaling and DNA methylation in cultured human prostate cells, suggests that PCZ might be one of the non-genotoxic promoters. Taken together, these findings are important for future assessment of endocrine disrupting pesticides, and we recommend that further studies should be needed to understand better the toxicity mechanisms of PCZ and especially, its role in epigenetic modifications.

Peer-review: Externally peer-reviewed.

Author contributions: Conception/Design of Study- S.Ö., E.F.K.; Data Acquisition- E.F.K., E.D., D.A.; Data Analysis/Interpretation- S.Ö., E.F.K.; Drafting Manuscript- S.Ö., E.F.K.; Critical Revision of Manuscript- S.Ö., E.F.K.; Final Approval and Accountability- E.F.K., E.D., D.A., S.Ö.

Conflict of Interest: The authors have no conflict of interest to declare.

Financial Disclosure: This work was supported in part by the Scientific Research Projects Coordination Unit of Istanbul University (Project numbers: TLO-2017-23409; TLO-2017-27475) and TUBITAK-BIDEB (Project numbers: 2211-C/2015-2).

\section{REFERENCES}

- $\quad$ Ahmad, I., Mui, E., Galbraith, L., Patel, R., Tan, E. H., Salji, M., \& Loveridge, C. (2016). Sleeping Beauty screen reveals Pparg activation in metastatic prostate cancer. Proceedings of the National Academy of Sciences, 113(29), 8290-8295.

- $\quad$ Ahmadnejad, M., Amirizadeh, N., Mehrasa, R., Karkhah, A., Nikougoftar, M., \& Oodi, A. (2017). Elevated expression of DNMT1 is associated with increased expansion and proliferation of hematopoietic stem cells co-cultured with human MSCs. Blood Research, 52(1), 25-30.

- Alley, M. C., Scudiere, D. A., Monks, A., Hursey, M. L., Czerwinski, M. J., Fine, D. L. ... Boyd, M. R. (1988). Feasibility of drug screening with panels of human tumor cell lines using a microculture tetrazolium assay. Cancer Research, 48, 589-601.
Alpertunga, B., Kara, M., Abudayyak, M., Oztas, E., Ozden, S., \& Özhan, G. (2014). Effects of prochloraz on DNA damage, lipid peroxidation and antioxidant system in vitro. Toxicology Mechanisms and Methods, 24(4), 268-275.

- Andersen, H. R., Vinggaard, A. M., Rasmussen, T. H., Gjermandsen, I. M., \& Bonefeld-Jørgensen, E. C. (2002). Effects of currently used pesticides in assays for estrogenicity, androgenicity and aromatase activity in vitro. Toxicology and Applied Pharmacology, 179, $1-12$.

Anderson, O. S., Sant, K. E., \& Dolinoy, D. C. (2012). Nutrition and epigenetics: an interplay of dietary methyl donors, one-carbon metabolism and DNA methylation. The Journal of Nutritional Biochemistry, 23(8), 853-859.

- $\quad$ Ayed-Boussema, I., Pascussi, J. M., Maurel, P., Bacha, H., \& Hassen, W. (2011). Zearalenone activates pregnane $X$ receptor, constitutive androstane receptor and aryl hydrocarbon receptor and corresponding phase I target genes mRNA in primary cultures of human hepatocytes. Environmental Toxicology and Pharmacology, 31(1), 79-87.

- Baylin, S. B. (1997). Tying it all together: epigenetics, genetics, cell cycle, and cancer. Science, 277(5334), 1948-1949.

- Bock, K. W., \& Kohle, C. (2005). Ah receptor- and TCDD-mediated liver tumor promotion: clonal selection and expansion of cells evading growth arrest and apoptosis. Biochemical Pharmacology, 69(10), 1403-1408.

- Casati, L., Sendra, R., Sibilia, V., \& Celotti, F. (2015). Endocrine disrupters: the new players able to affect the epigenome. Frontiers in Cell and Developmental Biology, 3, 37

- Claeys, W. L., Schmit, J. F., Bragard, C., Maghuin-Rogister, G., Pussemier, L., \& Schiffers, B. (2011). Exposure of several Belgian consumer groups to pesticide residues through fresh fruit and vegetable consumption. Food Control, 22, 508-16.

- Das, P. M., \& Singal, R. (2004). DNA methylation and cancer. Journal of Clinical Oncology, 22(22), 4632-4642.

- Decker, T., \& Lohmann-Matthes, M. L. (1988). A quick and simple method for the quantitation of lactate dehydrogenase release in measurements of cellular cytotoxicity and tumor necrosis factor (TNF) activity. Journal of Immunological Methods, 115(1), 61-69.

- $\quad$ Demirel, G., Alpertunga, B., \& Ozden, S. (2015). Role of fumonisin B1 on DNA methylation changes in rat kidney and liver cells. Pharmaceutical Biology, 53(9), 1302-1310.

- Derosa, G., Sahebkar, A., \& Maffioli, P. (2018). The role of various peroxisome proliferator-activated receptors and their ligands in clinical practice. Journal of Cellular Physiology, 233(1), 153-161.

EFSA (European Food Safety Authority). (2011). Conclusion on the peer review of the pesticide risk assessment of the active substance prochloraz. EFSA Journal, 9, 2323-443.

- $\quad$ Evans, B. R., Karchner, S. I., Allan, L. L., Pollenz, R. S., Tanguay, R. L., Jenny, M. J. ... Hahn, M. E. (2008). Repression of aryl hydrocarbon receptor (AHR) signaling by AHR repressor: Role of DNA binding and competition for AHR nuclear translocator. Molecular Pharmacology, 73, 387-398.

- Gama-Sosa, M. A., Slagel, V. A., Trewyn, R. W., Oxenhandler, R., Kuo, K. C., Gehrke, C. W., \& Ehrlich, M. (1983). The 5-methylcytosine content of DNA from human tumors. Nucleic Acids Research, 11(19), 6883-6894.

- Goettel, M., Melching-Kollmuss, S., Honarvar, N., Marxfeld, H., Elcombe, C. R., \& Fegert, I. (2015). Mouse liver tumors induced by prochloraz have a CAR-like mode of action and are not relevant to humans. Toxicological Sciences, 144(1), 351.

Greally, J. M., \& Jacobs, M. N. (2013). In vitro and in vivo testing methods of epigenomic endpoints for evaluating endocrine disruptors. Altex, 30(4), 445-71. 
- Halwachs, S., Wassermann, L., Lindner, S., Zizzadoro, C., \& Honscha, W. (2013). Fungicide prochloraz and environmental pollutant dioxin induce the $A B C G 2$ transporter in bovine mammary epithelial cells by the arylhydrocarbon receptor signaling pathway. Toxicological Sciences, 131(2), 491-501.

- Harada, K., Isse, K., Kamihira, T., Shimoda, S., \& Nakanuma, Y. (2005). Th1 cytokine-induced downregulation of PPARy in human biliary cells relates to cholangitis in primary biliary cirrhosis. Hepatology, 41(6), 1329-1338.

- Heise, T., Schmidt, F., Knebel, C., Rieke, S., Haider, W., Geburek, I. ... Marx-Stoelting, P. (2018). Hepatotoxic combination effects of three azole fungicides in a broad dose range. Archives of Toxicology, 92(2), 859-872.

- Heise, T., Schmidt, F., Knebel, C., Rieke, S., Haider, W., Pfeil, R. ... Marx-Stoelting, P. (2015). Hepatotoxic effects of (tri) azole fungicides in a broad dose range. Archives of Toxicology, 89(11), 21052117.

- Henry, M. J., \& Sisler, H. D. (1984). Effects of sterol biosynthesisinhibiting (SBI) fungicides on cytochrome P-450 oxygenations in fungi. Pesticide Biochemistry and Physiology, 22, 262-275.

- JMPR (The Joint FAO/WHO Meeting of Pesticide Residues). (2001). Report of the Joint Meeting of the FAO Panel of Experts on Pesticide Residues in Food and the Environment and the WHO. Core Assessment Group on Pesticide Residues, Geneva, Switzerland, pp. 17e26. September 2001, Report 2001.

- Jones, P. A., \& Baylin, S. B. (2007). The epigenomics of cancer. Cell, 128(4), 683-692.

- Karaman, E. F., \& Ozden, S. (2019). Alterations in global DNA methylation and metabolism-related genes caused by zearalenone in MCF7 and MCF10F cells. Mycotoxin Research, 35(3), 309-320.

- Korzeniewski, C., \& Callewaert, D. M. (1983). An enzyme-release assay for natural cytotoxicity. Journal of Immunological Methods, 64(3), 313-320.

- Kulis, M., \& Esteller, M. (2010). DNA methylation and cancer. Advances in Genetics, 70(10), 27-56.

- Lai, J. C., Cheng, Y. W., Goan, Y. G., Chang, J. T., Wu, T. C., Chen, C. Y., \& Lee, H. (2008). Promoter methylation of O 6-methylguanineDNA-methyltransferase in lung cancer is regulated by p53. DNA Repair, 7(8), 1352-1363.

- Laier, P., Metzdorff, S. B., Borch, J., Hagen, M. L., Hass, U., Christiansen, S. ... Vinggaard. A. M. (2006). Mechanisms of action underlying the antiandrogenic effects of the fungicide prochloraz. Toxicology and Applied Pharmacology, 213(2), 160-171.

- $\quad$ Laignelet, L., Riviere, J. L., \& Lhuguenot, J. C. (1992). Metabolism of an imidazole fungicide (prochloraz) in the rat after oral administration. Food and Chemical Toxicology, 30, 575-583.

- Long, M., Laier, P., Vinggaard, A. M., Andersen, H. R., Lynggaard, J., \& Bonefeld-Jørgensen, E. C. (2003). Effects of currently used pesticides in the AhR-CALUX assay: comparison between the human TV101L and the rat H4IIE cell line. Toxicology, 194(1-2), 77-93.

- Lundqvist, J., Hellman, B., \& Oskarsson, A. (2016). Fungicide prochloraz induces oxidative stress and DNA damage in vitro. Food and Chemical Toxicology, 91, 36-41.

- Maqbool, F., Mostafalou, S., Bahadar, H., \& Abdollahi, M. (2016). Review of endocrine disorders associated with environmental toxicants and possible involved mechanisms. Life Sciences, 145, 265-273.

- Marx-Stoelting, P., Ganzenberg, K., Knebel, C., Schmidt, F., Rieke, S., Hammer, H. ... Braeuning, A. (2017). Hepatotoxic effects of cyproconazole and prochloraz in wild-type and hCAR/hPXR mice. Archives of Toxicology, 91(8), 2895-2907.

- Mclntosh, B. E., Hogenesch, J. B., \& Bradfield, C. A. (2010). Mammalian Per-Arnt-Sim proteins in environmental adaptation. Annual Review of Physiology, 72, 625-645.
Michalik, L., \& Wahli, W. (2006). Involvement of PPAR nuclear receptors in tissue injury and wound repair. The Journal of Clinical Investigation, 116(3), 598-606.

Moggs, J. G., Goodman, J. I., Trosko, J. E., \& Roberts, R. A. (2004). Epigenetics and cancer: implications for drug discovery and safety assessment. Toxicology and Applied Pharmacology, 196(3), 422-430.

- Mosmann, T. (1983). Rapid colorimetric assay for cellular growth and survival: application to proliferation and cytotoxicity assays. Journal of Immunological Methods, 65(1-2), 55-63.

- $\quad$ Ohlsson, Å., Ullerås, E., \& Oskarsson, A. (2009). A biphasic effect of the fungicide prochloraz on aldosterone, but not cortisol, secretion in human adrenal H295R cellseunderlying mechanisms. Toxicology Letters, 191, 174-180.

- Olokpa, E., Bolden, A., \& Stewart, L. V. (2016). The androgen receptor regulates PPARy expression and activity in human prostate cancer cells. Journal of Cellular Physiology, 231, 2664-2672.

Pathania, R., Ramachandran, S., Elangovan, S., Padia, R., Yang, P., Cinghu, S. ... Thangaraju, M. (2015). DNMT1 is essential for mammary and cancer stem cell maintenance and tumorigenesis. Nature Communications, 6, 6910.

Pradhan, S., Bacolla, A., Wells, R. D., \& Roberts, R. J. (1999). Recombinant human DNA (cytosine-5) methyltransferase I. Expression, purification, and comparison of de novo and maintenance methylation. Journal of Biological Chemistry, 274(46), 33002-33010.

Rieke, S., Koehn, S., Hirsch-Ernst, K., Pfeil, R., Kneuer, C., \& MarxStoelting, P. (2014). Combination effects of (tri)azole fungicides on hormone production and xenobiotic metabolism in a human placental cell line. International Journal of Environmental Research and Public Health, 11(9), 9660-9679.

Robitaille, C. N., Rivest, P., \& Sanderson, J. T. (2015). Antiandrogenic mechanisms of pesticides in human LNCaP prostate and H295R adrenocortical carcinoma cells. Toxicological Sciences, 143(1), 126135.

Rogenhofer, S., Ellinger, J., Kahl, P., Stoehr, C., Hartmann, A., Engehausen, D. ... Walter, B. (2012). Enhanced expression of peroxisome proliferate-activated receptor $\gamma$ (PPAR- $\gamma$ ) in advanced prostate cancer. Anticancer Research, 32, 3479-3483.

Rogue, A., Lambert, C., Jossé, R., Antherieu, S., Spire, C., Claude, N., \& Guillouzo, A. (2011). Comparative gene expression profiles induced by PPARY and PPARa/Y agonists in human hepatocytes. PLoS One, 6(4), e18816.

- Rosa, S. C., Gonçalves, J., Judas, F., Mobasheri, A., Lopes, C., \& Mendes, A. F. (2009). Impaired glucose transporter-1 degradation and increased glucose transport and oxidative stress in response to high glucose in chondrocytes from osteoarthritic versus normal human cartilage. Arthritis Research \& Therapy, 11 (3), R80.

Rudzok, S., Krejči, S., Graebsch, C., Herbarth, O., Mueller, A., \& Bauer, M. (2011). Toxicity profiles of four metals and 17 xenobiotics in the human hepatoma cell line HepG2 and the protozoa Tetrahymena pyriformis-a comparison. Environmental Toxicology, 26(2), 171-186.

- $\quad$ Sanchez, W., Piccini, B., \& Porcher, J. M. (2008). Effect of prochloraz fungicide on biotransformation enzymes and oxidative stress parameters in three-spined stickleback (Gasterosteus aculeatus L.). Journal of Environmental Science and Health, Part B, 43, 65-70.

- Segawa, Y., Yoshimura, R., Hase, T., Nakatani, T., Wada, S., Kawahito, Y., \& Sano, H. (2002). Expression of peroxisome proliferator-activated receptor (PPAR) in human prostate cancer. The Prostate, 51(2), 108-116.

- $\quad$ Senyildiz, M., Karaman, E. F., Baş, S. S., Pirinççi, P. A., \& Ozden, S. (2016). Alteration on global and gene-spesific DNA methylation and global histone modifications in HepG2 cells in response to BPA. Journal of Faculty of Pharmacy of Istanbul University, 46(2), 97-114. 
- $\quad$ Senyildiz, M., Karaman, E. F., Bas, S. S., Pirincci, P. A., \& Ozden, S. (2017). Effects of BPA on global DNA methylation and global histone 3 lysine modifications in SH-SY5Y cells: An epigenetic mechanism linking the regulation of chromatin modifying genes. Toxicology In Vitro, 44, 313-321.

- $\quad$ Sturm, A., Cravedi, J. P., Perdu, E., Baradat, M., \& Segner, H. (2001). Effects of prochloraz and nonylphenol diethoxylate on hepatic biotransformation enzymes in trout: a comparative in vitro/in vivo-assessment using cultured hepatocytes. Aquatic Toxicology, 53(3-4), 229-245.

- Vinggaard, A. M., Hass, U., Dalgaard, M., Andersen, H. R., BonefeldJørgensen, E., Christiansen, S. ... Poulsen, M. E. (2006). Prochloraz: An imidazole fungicide with multiple mechanisms of action. International Journal of Andrology, 29, 186-192.
Vinggaard, A. M., Hnida, C., Breinholt, V., \& Larsen, J. C. (2000). Screening of selected pesticides for inhibition of CYP19 aromatase activity in vitro. Toxicology In Vitro, 14, 227 e234.

- Vinggaard, A. M., Nellemann, C., Dalgaard, M., Jorgensen, E. B., \& Andersen, H. R. (2002). Antiandrogenic effects in vitro and in vivo of the fungicide prochloraz. Toxicological Sciences, 69, 344-353.

- Watson, R. E., \& Goodman, J. I. (2002). Epigenetics and DNA methylation come of age in toxicology. Toxicological Sciences, 67(1), $11-16$. 